\title{
BOOKS AND PAMPHLETS RECEIVED
}

Allen, Robert M., Ph.D. Introduction to the Rorschach Technique: Manual of Administration and Scoring. International Universities Press, New York, 1953. Paper. pp. 126. $\$ 3$.

Bernhardt, Karl S., Ph.D. Practical Psychology. 2d ed. McGraw-Hill, New York, 1953. pp. 337. \$3.75.

Clark, Robert A., M.D. Six Talks on Fung's Psychology. Boxwood Press, Pittsburgh, 1953. Paper. pp. 84. $\$ 1.50$.

Cruze, Wendell W. Adolescent Psychology and Development. Ronald Press, New York, 1953. pp. 557. $\$ 5$.

Davis, Annie Lee. Children Living in Their Own Homes: Social Services Provided Through Child Welfare Programs. Children's Bureau Publ. No. 339. U. S. Government Printing Office, Washington, D. C., 1953. pp. 52.20 cents.

Duvall, Evelyn Millis, Ph.D., and Reuben Hill, Ph.D. When You Marry. Revised ed. Heath, Boston, 1953. pp. 466. \$3.50.

Green, Sidney L., M.D., and Alan B. Rothenberg, M.A. A Manual of First Aid for Mental Health: In Childhood and Adolescence. Julian Press, New York, 1953. pp. 278. $\$ 4$.

Grinker, Roy R., M.D. (Ed.). Mid-Century Psychiatry. Charles C Thomas, Springfield, Ill., 1953. pp. 183.

Halmos, Paul. Solitude and Privacy: A Study of Social Isolation, Its Causes and Therapy. Philosophical Library, New York, 1953. pp. 181. \$4.75.

Jones, Maxwell, M.D. The Therapeutic Community: A New Treatment Method in Psychiatry. Basic Books, New York, 1953. pp. 186. \$3.50.

Kahn, Theodore C. Manual for the Kahn Test of Symbol Arrangement. Revised and enlarged, 1953. pp. 70. (The author, Medical Gr., N.P. Service, Parks A. F. Base, Calif.)

Katz, Barney, Ph.D., and George F. J. Lehner, Ph.D. Mental Hygiene in Modern Living. Ronald Press, New York, 1953. pp. 544. \$4.50.
Kempf, Edward J., et al. Comparative Conditioned Neuroses. Annals of New York Academy of Sciences, Vol. 56, Art. 2. Published by the Academy, New York, 1953. pp. 300. \$3.50.

Patterson, C. H. The Wechsler-Belleoue Scales: A Guide for Counselors. Charles C Thomas, Springfield, Ill., 1953. pp. 146. $\$ 3.75$.

Podolsky, Edward, M.D. (Ed.). Encyclopedia of Aberrations: A Psychiatric Handbook. Philosophical Library, New York, 1953. pp. $550 . \$ 10$.

Reiss, Samuel. The Universe of Meaning. Philosophical Library, New York, 1953. pp. 227. \$3.75.

Riese, Walther, M.D. The Conception of Disease: Its History, Its Versions and Its Nature. Philosophical Library, New York, 1953. pp. 120. \$3.75.

Ruggles, Arthur H., M.D. The Place and Scope of Psychotherapy. Salmon Committee on Psychiatry and Mental $\mathrm{Hy}$ giene, New York, 1952. pp. 96.

Runes, Dagobert D. The Sooiet Impact on Society. Philosophical Library, New York, 1953. pp. 202. \$3.75.

Sadler, William S., M.D. Practice of Psychiatry. Mosby, St. Louis, 1953. pp.1183.\$15.

Senn, Milton J. E., M.D. (Ed.). Problems of Infancy and Childhood: Transactions of the Sixth Conference, 1952. Josiah Macy, Jr. Foundation, New York, 1953. pp. 160. $\$ 2.50$.

Steiner, Lee R. A Practical Guide for Troubled People. Greenberg, New York, 1952. pp. 299. \$3.50.

Stenstedt, Ake. A Study in Manic-Depressive Psychosis. Munksgaard, Copenhagen, 1952. Paper. pp. 111. 20 Swed. crowns.

Wolf, Stewart, M.D., and Harold G. Wolff, M.D. Headaches: Their Nature and Treatment. Little, Brown, Boston, 1953. pp. 177. \$2.50.

Zietz, Dorothy, Ph.D. Social Welfare Information for Teachers. Published by author, East Lansing, Michigan, 1952. pp. 92. \$1. 